\title{
Separation-Induced Receptor Changes in the Hippocampus and Amygdala of Octodon degus: Influence of Maternal Vocalizations
}

\author{
Irina Ziabreva, ${ }^{1}$ Gerd Poeggel, ${ }^{2}$ Reinhild Schnabel, ${ }^{1}$ and Katharina Braun ${ }^{1}$ \\ ${ }^{1}$ Department of Zoology/Developmental Neurobiology, Otto-von-Guericke-University, 39118 Magdeburg, Germany, and ${ }^{2}$ University of Leipzig, Zoological \\ Institute, 04103 Leipzig, Germany
}

\begin{abstract}
Relatively little is known about the basic mechanisms that play a role in the vulnerability of the developing brain toward adverse environmental influences. Our study in the South American rodent Octodon degus revealed that repeated brief separation from the parents and exposure to an unfamiliar environment induces in the hippocampal formation of male and female pups an upregulation of $\mathrm{D}_{1}$ and $5-\mathrm{HTl}_{\mathrm{A}}$ receptor density in the stratum radiatum and stratum lacunosum moleculare of the CA1 region. In the CA3 region, only the $5-\mathrm{HT}_{\mathrm{A}}$ receptors were upregulated; no changes were observed for $\mathrm{D}_{1}$ receptors in this region. $\mathrm{GABA}_{\mathrm{A}}$ receptor density in the hippocampus and amygdala was downregulated (nonsignificant trend) after parental separation.

The acoustic presence of the mother during parental separation suppressed the $\mathrm{D}_{1}$ and $5-\mathrm{HT} 1_{\mathrm{A}}$ receptor upregulation in some regions of the hippocampus; no such suppressing influence was observed for the $\mathrm{GABA}_{\mathrm{A}}$ receptors. In the basomedial amygdala, the maternal calls enhanced the separation-induced $5-\mathrm{HT}_{\mathrm{A}}$ receptor upregulation in the male pups, whereas in the female pups the separationinduced receptor densities were not only suppressed by the maternal call but further downregulated, compared with the control group. These results demonstrate that early adverse emotional experience alters aminergic function within the hippocampus and amygdala and that the mother's voice, a powerful emotional signal, can modulate these effects in the developing limbic system.
\end{abstract}

Key words: hippocampus; amygdala; stress; parental separation; $\mathrm{D}_{1}$ receptors; $5 \mathrm{HT}_{\mathrm{A}}$ receptors; $\mathrm{GABA}_{\mathrm{A}}$ receptors; quantitative autoradiography; limbic system

\section{Introduction}

Subtle interactions of environmental signals with genes that drive neuronal differentiation and the formation of synapses and brain circuits are required for the normal development of functional brain circuits. The development of limbic structures such as the hippocampus and the amygdala can be modulated by sensory as well as emotional experience during early postnatal life (Walsh, 1981; Martin et al., 1991; Sutanto et al., 1996; Avishai-Eliner et al., 1999; Joseph, 1999; Swann et al., 1999; Vazquez et al., 2000; Chugani et al., 2001). This adaptability of the developing brain toward adverse environmental influences such as sensory and emotional deprivation or stress has been studied in various animal models. Application of paradigms for stressful experience such as maternal separation and the exposure to an unfamiliar environment has been shown to induce altered aminergic transmitter function (Tamborski et al., 1990; Jones et al., 1992; Harvey et al., 1994; Kehoe et al., 1996; Hall et al., 1999; Braun et al., 2000; Caldji et al., 2000; Ziabreva et al., 2000; Matthews et al., 2001; Meaney et al., 2002; Neumaier et al., 2002) as well as long-term changes of synaptic composition (Helmeke et al., 2001a,b), that are accompanied by behavioral changes (Hall, 1998; Braun et al., 2003).

Received Dec. 23, 2002; revised March 14, 2003; accepted March 25, 2003.

This work was supported by a grant of the state Saxony-Anhalt and by the VolkswagenStiftung.

Correspondence should be addressed to Dr. Katharina Braun, Department of Zoology/Developmental Neurobiology, Otto-von-Guericke-University, c/o Leibniz Institute for Neurobiology, Brenneckestrasse 6, 39118 Magdeburg, Germany. E-mail: katharina.braun@nat.uni-magdeburg.de.

Copyright $\odot 2003$ Society for Neuroscience $\quad 0270-6474 / 03 / 235329-08 \$ 15.00 / 0$
Monoaminergic and GABAergic systems modulate emotional and motivational aspects of behavior such as anxiety and reward and punishment situations. Transient or lasting experienceinduced changes of these transmitter systems in limbic structures, which mediate emotional behaviors as well as learning and memory formation, may result in altered cognitive and socioemotional capabilities at later stages of life. Thus, one aim of this study was to localize, autoradiographically, the region-specific changes of dopaminergic, serotonergic, and GABAergic transmitter receptors in the hippocampus and the amygdala after a stressful and fear-inducing situation, i.e., separation from the family and exposure to a novel environment.

The consequences of early aversive environmental stimuli on brain function can be ameliorated or prevented by the interaction with the mother via her sensory signals, including visual, olfactory, tactile, and acoustic stimuli (Fleming et al., 1999). Maternal vocalization is an essential part of the establishment and maintenance of the infant-mother attachment and mental development not only in humans (Barnard and Bee, 1983; Fifer and Moon, 1994) but also in the species investigated in this study (Reynolds and Wright, 1979; Poeggel and Braun, 1996; Braun and Scheich, 1997; Braun and Poeggel, 2001). Pups of the South American species Octodon degus are born with open eyes and ears, similar to human newborns (DeCasper and Fifer, 1980; Fifer and Moon, 1994), which allows them to recognize, learn, and interpret acoustic signals (Poeggel and Braun, 1996; Braun and Poeggel, 2001) and to discriminate between familiar and novel environments immediately after birth. Thus, the second aim of this study 
was to investigate a possible protective role of maternal signals, i.e., maternal vocalizations, on separation-induced transmitter receptor changes.

\section{Materials and Methods}

Housing conditions

The degus were bred in our colony. Family groups consisting of an adult couple and their offspring were housed in standard rat cages (length $\times$ height $\times$ depth: $53 \times 24 \times 32 \mathrm{~cm}$ ) and exposed to a $12 \mathrm{hr}$ light/dark cycle. Fresh drinking water and rat diet pellets, vegetables, and fruits were available ad libitum. The rooms were air-conditioned, with an average temperature of $22^{\circ} \mathrm{C}$. Short separation from the parents and siblings started on postnatal day (P) 8 and was continued until P10 (the day of birth was considered as $\mathrm{P} 0$ ).

\section{Experimental groups}

Separation from the parents and siblings (SP group: $\mathrm{N}_{\text {female }}=6 ; \mathrm{N}_{\text {male }}=5$ ). The pups were taken out of the home cage and individually exposed for 3 min to an unfamiliar environment, an open field arena (length $\times$ depth $\times$ height: $0.7 \times 0.7 \times 0.25 \mathrm{~m}$; the color of the open field was light gray). The light levels in the testing room were kept at $1.5 \mathrm{Lux}$. The floor and the walls of the arena were carefully wiped with $70 \%$ ethanol and dried with a fresh paper towel between each animal. Two separation periods (between 8 and 9 A.M. and between 2 and 3 P.M.), 3 min each per day, were performed, resulting in a total of six separation periods. After the last separation period on P10, the pups remained undisturbed with their families until P14.

Separation from the parents and siblings and tone stimulation ( $S P+T$ group: $\mathrm{N}_{\text {female }}=6 ; \mathrm{N}_{\text {male }}=6$ ). The procedure for these animals was identical to the SP group except that the maternal call (= tone) was presented during the $3 \mathrm{~min}$ of parental separation. Details of the acoustic features of the maternal call are in Poeggel and Braun (1996) and Braun and Scheich (1997). Maternal calls from a lactating female degu that was unfamiliar to the tested pups were presented via two loudspeakers. For all litters and experiments the same maternal call was used to keep the acoustic stimulus parameters identical. In previous experiments the same set of vocalizations has been shown to evoke behavioral responses (Poeggel and Braun, 1996; Braun and Poeggel, 2001; Braun et al., 2003) and to activate prefrontal cortical regions, including the anterior cingulate cortex (Poeggel and Braun, 1996; Braun and Scheich, 1997) in normal, nondeprived degu pups. In contrast to all other calls (warning calls, contact calls), which have a duration of $<1 \mathrm{sec}$, the maternal call may last several seconds. It consists of two elements: a long repetitive rattling followed by a constant frequency of slowly modulated peep tone. The rattling is a pulse-like, steep up and down frequency modulation between 0.3 and $3.5 \mathrm{kHz}$, whereas the frequency of the peep varies around $2 \mathrm{kHz}$ (Braun and Scheich, 1997). One such call of $\sim 3 \mathrm{sec}$ duration was used here in a repetitive mode ( 20 per minute), whereas in a normal situation such calls are uttered by mothers for up to $60 \mathrm{sec}$ (average duration of a sequence $15 \mathrm{sec}$.

Control group (control: $\mathrm{N}_{\text {female }}=8 ; \mathrm{N}_{\text {male }}=5$ ). These pups remained undisturbed with their families until P14.

\section{Ligand binding autoradiography}

The animals of all three groups were killed at the age of P14, and their brains were processed for autoradiography. The autoradiographic procedure was performed according to Schnabel and Braun (1996) and is summarized in Table 1. Slides with serial sections from each experimental group (control, $\mathrm{SP}$, and $\mathrm{SP}+\mathrm{T}$ ) were incubated simultaneously with the radioactive compounds $\left[{ }^{3} \mathrm{H}\right] \mathrm{SCH} 23390$ ([R-(+)-8-chlor-2,3,4,5-tetrahydro-3-methyl5-phenyl-1H-3-benzazepin-7-ol(Z)-2-butenedioate), [ $\left.{ }^{3} \mathrm{H}\right]$-OH-DPAT ( $N, N$-dipropyl-8-hydroxy-2-aminotetralin), and $\left[{ }^{3} \mathrm{H}\right]$ muscimol (5(aminomethyl)-3(2H)-isoxazolone) (NEN, Köln, Germany). For quantitative analysis, slides together with tritium standards (Biotrend, Köln, Germany) were exposed to imaging plates (Fuji, Tokyo, Japan) with a $\beta$-ray emission-sensitive phosphor crystal layer for $6 \mathrm{~d}$. The resulting radiation from imaging plates was read by the scanner unit of the imaging system BAS3000 (Fuji). During the scanning procedure the photostimulable phosphor crystal of the plate emits intensified light [photostimu-
Table 1. Incubation protocol for receptor autoradiography

\begin{tabular}{|c|c|c|}
\hline$D_{1}$ receptors & 5-HT1 $1_{A}$ receptors & $\mathrm{GABA}_{\mathrm{A}}$ receptors \\
\hline $\begin{array}{l}\text { Incubation with } 3 \mathrm{~nm} \\
\left.{ }^{3} \mathrm{H}\right] \mathrm{SCH} 23390 \text { (72.8 } \\
\mathrm{Ci} / \mathrm{mmol} \text { ) in } 50 \mathrm{~mm} \\
\text { Tris- } \mathrm{HCl} \text { containing } \\
120 \mathrm{~mm} \mathrm{NaCl}, 5 \mathrm{~mm} \\
\mathrm{KCl}, 2 \mathrm{~mm} \mathrm{CaCl}, 1 \mathrm{~mm} \\
\mathrm{MgCl}_{2}, \mathrm{pH} 7.4 \text {, and } \\
100 \mathrm{~nm} \text { mianserin (to } \\
\text { block unspecific } \\
\text { binding to the 5-HT2 } \\
\text { receptor) }\end{array}$ & $\begin{array}{l}\text { Incubation with } 15 \mathrm{~nm}\left[{ }^{3} \mathrm{H}\right]-0 \mathrm{H}- \\
\text { DPAT }(127 \mathrm{Ci} / \mathrm{mmol}) \text { in } 170 \\
\text { mm Tris- } \mathrm{HCl} \text { containing } 4 \\
\mathrm{~mm} \mathrm{CaCl} \text { and } 1 \% \text { ascorbic } \\
\text { acid at } 4^{\circ} \mathrm{C}^{a}\end{array}$ & $\begin{array}{l}\text { Incubation with } 100 \mathrm{~nm} \\
\left.\qquad{ }^{3} \mathrm{H}\right] \text { muscimol }(10.1 \mathrm{Ci} / \\
\mathrm{mmol}) \text { in } 170 \mathrm{~mm} \text { Tris- } \mathrm{HCl}^{a}\end{array}$ \\
\hline $\begin{array}{l}100 \text { nm SCH23390 (RBI, } \\
\text { Natick, MA) }\end{array}$ & $50 \mu \mathrm{m} 5-\mathrm{HT}^{b}$ & $100 \mu \mathrm{m} \mathrm{muscimol}^{b}$ \\
\hline $2 \times$ for $6 \min ^{c}$ & $2 \times$ for $5 \min ^{c}$ & $2 \times$ for $10 \sec ^{c}$ \\
\hline
\end{tabular}

${ }^{a}$ Cryosections (10 $\mu \mathrm{m}$ thick) were thawed on glass slides, air dried, and then preincubated in the incubation buffer at $4^{\circ} \mathrm{C}$ for $30 \mathrm{~min}$. The incubation lasts for $1 \mathrm{hr}$ at room temperature.

${ }^{b}$ Test for nonspecific binding: parallel incubation of adjacent sections in their presence.

Incubation was terminated by rinsing the sections in the incubation buffer. Then they were briefly dipped in cold distilled water and dried in a stream of cold air.

Table 2. Brain regions analyzed for receptor density

\begin{tabular}{|c|c|}
\hline Receptor subtypes & Analyzed regions \\
\hline \multicolumn{2}{|l|}{$D_{1}$ receptor } \\
\hline Hippocampus & $\begin{array}{l}\text { CA1/stratum radiatum (CA1/Rad), CA1/stratum lacunosum moleculare } \\
\text { (CA1/LMol), CA3 }\end{array}$ \\
\hline Amygdala & $\begin{array}{l}\text { Basomedial amygdaloid nucleus (BM), basolateral amygdaloid nucleus } \\
\text { (BL), central amygdaloid nucleus (Ce) }\end{array}$ \\
\hline \multicolumn{2}{|l|}{ 5-HT1 $1_{A}$ receptor } \\
\hline Hippocampus & $\begin{array}{l}\text { CA1/stratum radiatum (CA1/Rad), molecular layer of the dentate gyrus } \\
\text { (DG/Mol), } \mathrm{CA} 3 / \text { stratum radiatum (CA3/Rad) }\end{array}$ \\
\hline Amygdala & Basomedial amygdaloid nucleus (BM) \\
\hline \multicolumn{2}{|l|}{$\mathrm{GABA}_{\mathrm{A}}$ receptor } \\
\hline Hippocampus & $\begin{array}{l}\text { Hippocampus: } \mathrm{CA} 1 / \text { stratum radiatum (CA1/Rad), molecular layer of } \\
\text { the dentate gyrus (DG/Mol), } C A 3 / \text { stratum radiatum (CA3/Rad) }\end{array}$ \\
\hline Amygdala & Lateral amygdaloid nucleus (La) \\
\hline
\end{tabular}

lated luminescence (PSL)] in proportion to the primary excitation from the radiation. This PSL was measured in each measuring field (integrated PSL over the area) of the brain and in the tritium standards, and after subtraction of the background it was calculated per square millimeter using TINA2.9 software. (Raytest, Straubenhardt, Germany). To test for gender-specific variations and hemispheric asymmetries, all quantitative analyses have been performed separately for male and female pups and for right and left hemisphere, respectively. For each animal and brain region, six sections over a rostrocaudal extension of $250 \mu \mathrm{m}$ were measured, for which the mean densities were calculated. Brain areas, summarized in Table 2, were selected for quantitative analysis according to their distinct labeling and clear identification from adjacent areas. In some cases sections counterstained with cresyl violet were used for definition of hippocampal subregions and amygdaloid nuclei, which were identified according to the degu brain atlas (Wright and Kern, 1992).

In the present study we used saturable ligand concentrations, determined in saturation binding experiments and Scatchard plots (data not shown), to analyze the maximal binding to the receptor. The receptor densities were calculated as molar quantities of the bound radioligand per unit protein (femtomole per milligram) by calibration of the measured PSL against the tritium standards (Biotrend) as nanocuries per milligram that were converted into femtomole per milligram. The data from receptor ligand binding (bound ligand per unit protein) experiments were analyzed by the Kruskal-Wallis one-way ANOVA (significant difference was set at $p \leq 0.05$ ) followed by two-tailed Mann-Whitney $U$ test. 


\section{Results}

Dopaminergic $\mathrm{D}_{1}$ receptors

Compared with prefrontal cortical regions (Ziabreva et al., 2003), the hippocampus displayed very low $\mathrm{D}_{1}$ receptor density (Fig. $1 A)$. The amygdaloid complex, a region with varying densities of $\mathrm{D}_{1}$ receptor binding, displays moderate levels of $\mathrm{D}_{1}$ receptor density in the basomedial and central nucleus and lower binding in the basolateral nucleus (Fig. 1A).

\section{5-HT1 $1_{\mathrm{A}}$ receptors}

The CA1/stratum radiatum, CA1/stratum lacunosum moleculare, and CA3 region of hippocampus displayed a moderate to high level of $5-\mathrm{HT}_{\mathrm{A}}$ receptor density (Fig. $1 \mathrm{~B}$ ). The distribution of $5-\mathrm{HT} 1_{\mathrm{A}}$ receptors in the amygdala was generally homogeneous, with moderate to high density in the basomedial amygdaloid nucleus (Fig. $1 B$ ). Gender differences of $5-\mathrm{HT}_{\mathrm{A}}$ receptor density were detected. In the molecular layer of the dentate gyrus and the stratum radiatum of the CA3 field of the hippocampus, the female pups displayed significantly higher $5-\mathrm{HT} 1_{\mathrm{A}}$ receptor densities than male pups (see Fig. 4).

\section{$\mathrm{GABA}_{\mathrm{A}}$ receptors}

The hippocampus showed a moderate density of $\mathrm{GABA}_{\mathrm{A}}$ receptor in $\mathrm{CA} 1 /$ stratum radiatum and CA3 regions with higher receptor labeling in the molecular layer of the dentate gyrus. Within the amygdaloid complex, moderate to high receptor binding was observed in the lateral amygdaloid nucleus (Figs. $1 C, 5$ ).

Because none of the receptors displayed asymmetric distributions in any experimental animal groups, the measurements for both hemispheres were pooled.

\section{Changes of receptor densities after parental separation in a novel environment \\ Dopaminergic $D_{1}$ receptors}

After repeated short parental separation (SP group), $\mathrm{D}_{1}$ receptor density increased in the female pups in all measured layers of the CA1 hippocampal region (Fig. 2) compared with the control group. The male pups of the SP group showed significant $D_{1}$ receptor upregulation only in the stratum radiatum of the CA1 area compared with controls (Fig. 2). No changes were observed in the CA3 region of either gender. In all investigated amygdaloid nuclei (Table 2), only the female pups displayed a significant increase of $\mathrm{D}_{1}$ receptor density in comparison with the normal controls (Fig. 3, group C).

\section{Serotonergic $5-H T 1_{A}$ receptors}

Repeated brief parental separation (SP group) induced a significant increase of $5-\mathrm{HT} 1_{\mathrm{A}}$ receptor density in all hippocampal regions and layers in male and female pups (Fig. 4, Table 2) compared with normal controls. In the basomedial amygdaloid nucleus, short-term parental separation did not induce any significant changes in either gender (Fig. 4).

\section{$G A B A_{A}$ receptors}

In relation to the untreated control group, the $\mathrm{GABA}_{\mathrm{A}}$ receptor density was decreased in the hippocampus and amygdala, especially in the male pups, after parental separation; however, these differences did not reach statistical significance (Fig. 5, Table 2).

\section{Protective effects of maternal vocalizations during parental separation}

Dopaminergic $D_{1}$ receptors

In male but not in female pups, the presentation of the maternal vocalizations during separation from the mother ("acoustic pres-
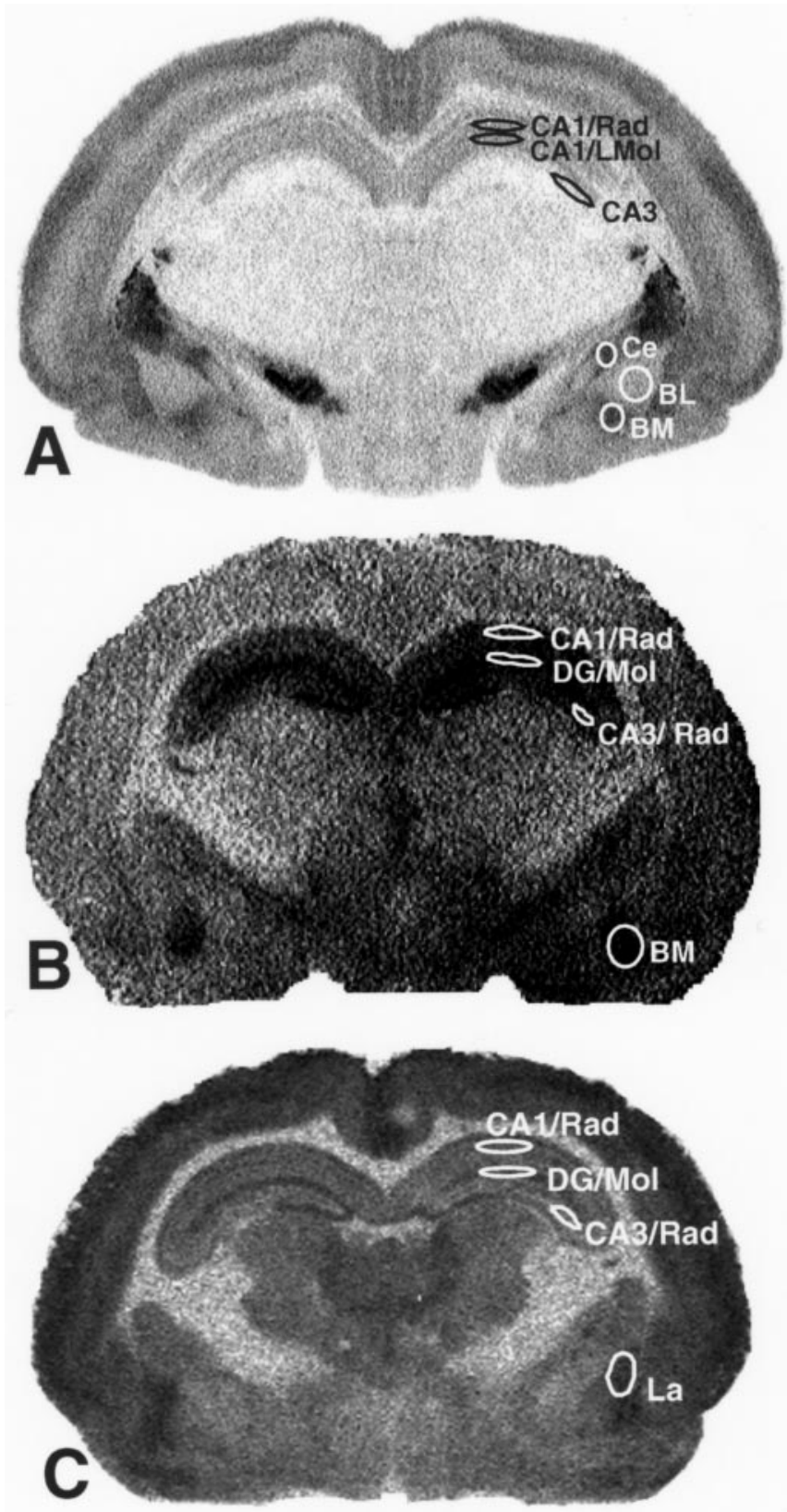

Figure 1. Subregions of the hippocampus and amygdala. $A_{,}\left[{ }^{3} \mathrm{H}\right]-\mathrm{SCH} 23390$ used as dopamine D1 receptor ligand. $B,\left[{ }^{3} \mathrm{H}\right]-\mathrm{OH}$-DPAT used as 5 -HT1A receptor ligand. $C^{3}{ }^{3} \mathrm{H}$-muscimol used as $\mathrm{GABA}_{A}$ receptor ligand. The relatively poor spatial resolution of these images is the result of the use of imaging plates, which provide a better linearity of ${ }^{14} \mathrm{C}-$ sensitivity and a resolution of $>4000$ gray values but a relatively poor spatial image resolution compared with conventional $x$-ray films. CA1, CA3, Fields in the hippocampus; Rad, LMol, stratum radiatum and stratum lacunosum moleculare of CA fields; DG, dentate gyrus; DG/Mol, stratum moleculare of dentate gyrus; $C$, central nucleus of the amygdala; $B M$, basomedial nucleus of the amygdala; $B L$, basolateral nucleus of the amygdala; La, lateral nucleus of the amygdala.

ence of the mother") suppresses the separation-induced $D_{1}$ receptor upregulation in the stratum radiatum of the CA1 region; i.e., the receptor concentrations in this group remained in the same range as in the control group (Fig. 2). No significant effect of maternal vocalizations on the separation-induced $D_{1}$ receptor upregulation was found in the hippocampal CA1 stratum lacunosum moleculare and CA3 region regions (Fig. 2). In the female pups, the maternal call prevented the separation-induced receptor changes in the basomedial and central amygdaloid nuclei (Fig. 

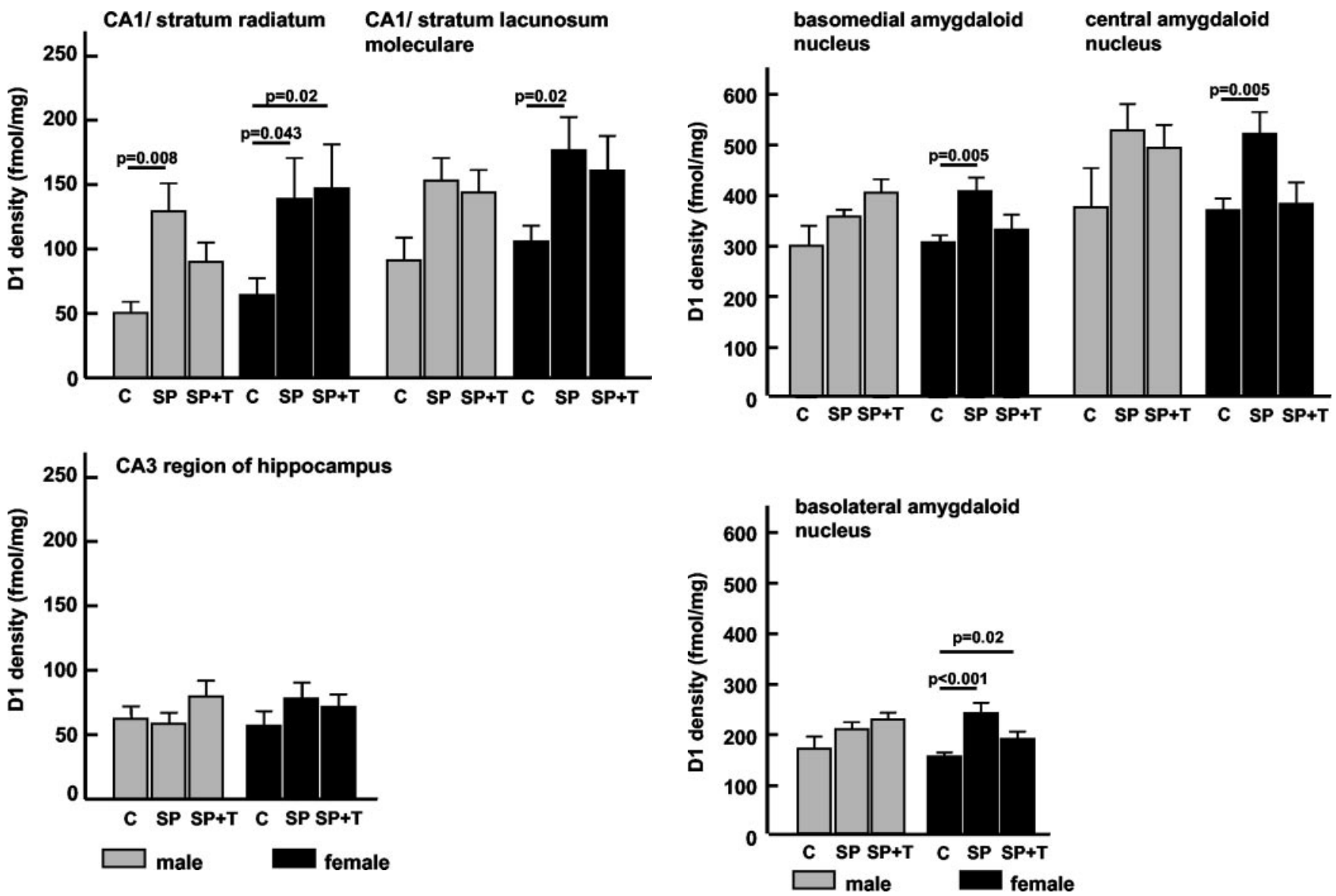

Figure 2. Repeated brief parental separation in an unfamiliar environment induced a significant increase in $D_{1}$ receptor density in the $C A 1$ but not in the $C A 3$ region of the hippocampus. The presentation of maternal vocalizations during parental separation suppressed D1 receptor upregulation in the stratum radiatum of male pups; no such effect was seen in the other regions of male and female pups. Values are mean with $\mathrm{SE} ; p$ values indicate results of two-tailed Mann-Whitney U test. C, Control group; SP, separation from parents; SP +T, separation from parents + tone (maternal calls).

3); i.e., the receptor concentrations in this group remained in the same range as in the control group.

\section{Serotonergic $5-H T 1_{A}$ receptors}

The presentation of the maternal call ( $\mathrm{SP}+\mathrm{T}$ group) had a significant suppressive effect on separation-induced $5-\mathrm{HT} 1_{\mathrm{A}}$ receptor upregulation in all investigated hippocampal regions of the female pups (Fig. 4). A similar but milder suppressive effect of the maternal calls was seen in the male pups. In contrast, in the basomedial amygdala of the male pups the maternal calls enhanced the separation-induced receptor upregulation (Fig. 4), whereas in the female pups, the separation-induced receptor densities were not only suppressed by the maternal call but went even below the values of the control group (Fig. 4).

\section{$G A B A_{A}$ receptors}

The acoustic presence of the mother during the separation period restored $\mathrm{GABA}_{\mathrm{A}}$ receptor density in the hippocampus and the amygdala of male pups; i.e., the receptor densities in the $\mathrm{SP}+\mathrm{T}$ group were similar to the levels in the control group (Fig. 5). In the female pups, similar but weaker effects were observed.

Figure 3. Repeated brief parental separation in an unfamiliar environment induced a significant increase in $D_{1}$ receptor density in the amygdala of female pups; the same trend was observed in the male pups. The presentation of maternal vocalizations during parental separation suppressed D1 receptor upregulation in the female pups; no such effect was seen in the male pups. Values are mean with SE; $p$ values indicate results of two-tailed Mann-Whitney $U$ test. C, Control group; SP, separation from parents; $\mathrm{SP}+\mathrm{T}$, separation from parents + tone (maternal calls).

\section{Discussion}

Effects of parental separation in a novel environment on receptor densities

Dopamine: $D_{1}$ receptors

Behavioral pharmacological and neurochemical experiments revealed that the mesolimbic dopamine system in young animals is strongly involved in the so-called "isolation syndrome" (Clancy and McBride, 1975). The $\mathrm{D}_{1}$ receptor upregulation found in our experiments after very early, i.e., preweaning parental separation, is in line with similar observations in the maternal separation paradigm used in laboratory rats, where changes of dopamine turnover and receptors have been found in the striatum and septum (Kehoe et al., 1996). In adult rats after repeated maternal separation, increased tissue levels of dopamine were found in dorsal and ventral striatum, and decreased turnover of dopamine was measured in the medial prefrontal cortex (mPFC) (Matthews et al., 2001). In guinea pig, maternal separation from the mother increased dopamine turnover in the septum and hypothalamus; again, this effect occurred only in the context of novelty (Tamborski et al., 1990; Harvey et al., 1994).

Imbalances of the dopamine system have been described after postweaning chronic social isolation; e.g., increased levels of noradrenaline, dopamine, and its metabolites were measured in the cortex and dorsal and ventral (nucleus accumbens) striatum of 

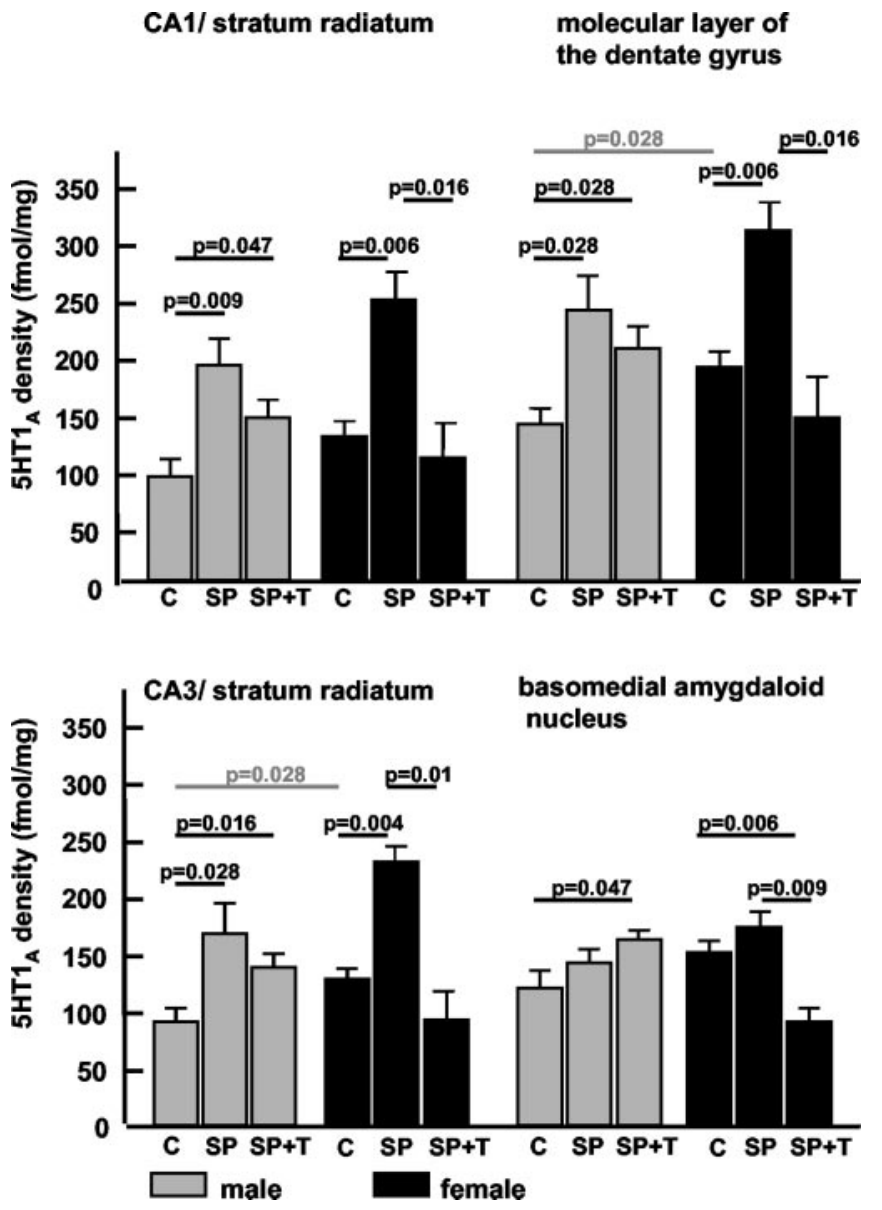

Figure 4. Repeated brief parental separation in an unfamiliar environment induced a significant increase in $5-\mathrm{HT} 1_{\mathrm{A}}$ receptor density in the hippocampus of both genders; a slight trend in the same direction was observed in the basomedial amygdala. The presentation of maternal vocalizations during parental separation strongly downregulated $5-\mathrm{HT} 1_{A}$ receptor upregulation in the hippocampus and basomedial amygdala of female pups. In male pups, a similar but weaker effect was seen in the hippocampus but not in the amygdala. Values are mean with SE; $p$ values indicate results of two-tailed Mann-Whitney $U$ test. Differences of basal receptor levels (control groups) between the genders are indicated by the gray bars. C, Control group; SP, separation from parents; $\mathrm{SP}+\mathrm{T}$, separation from parents + tone (maternal calls).

rats. These neurochemical changes are accompanied by enhanced locomotor activities in a novel environment (open field) (Hall et al., 1998; Braun et al., 2003).

Serotonin: $5-H T 1_{A}$ receptors

Several studies have shown that $5-\mathrm{HT} 1_{\mathrm{A}}$ receptors are involved in response to acute or chronic stress (Mendelson and McEwen, 1991; Flugge et al., 1998), social isolation (Coudereau et al., 1995), and environmental enrichment (Rasmuson et al., 1998). Serotonin itself appears to be downregulated in the dorsal hippocampus and in the mPFC of rat pups after repeated maternal separation (Matthews et al., 2001), which may indicate counterbalanced regulation between the transmitter and this receptor subtype.

Exposure to stressful events (parental separation) was induced during a period during which the serotonergic afferent systems in the degu and rat brain are still developing and thus may be particularly sensitive to environmental and experimental influences (Daval et al., 1987; Borella et al., 1997; Braun et al., 2000). We speculate that changes in the serotonergic system induced by parental separation or other stressors, which occur during such
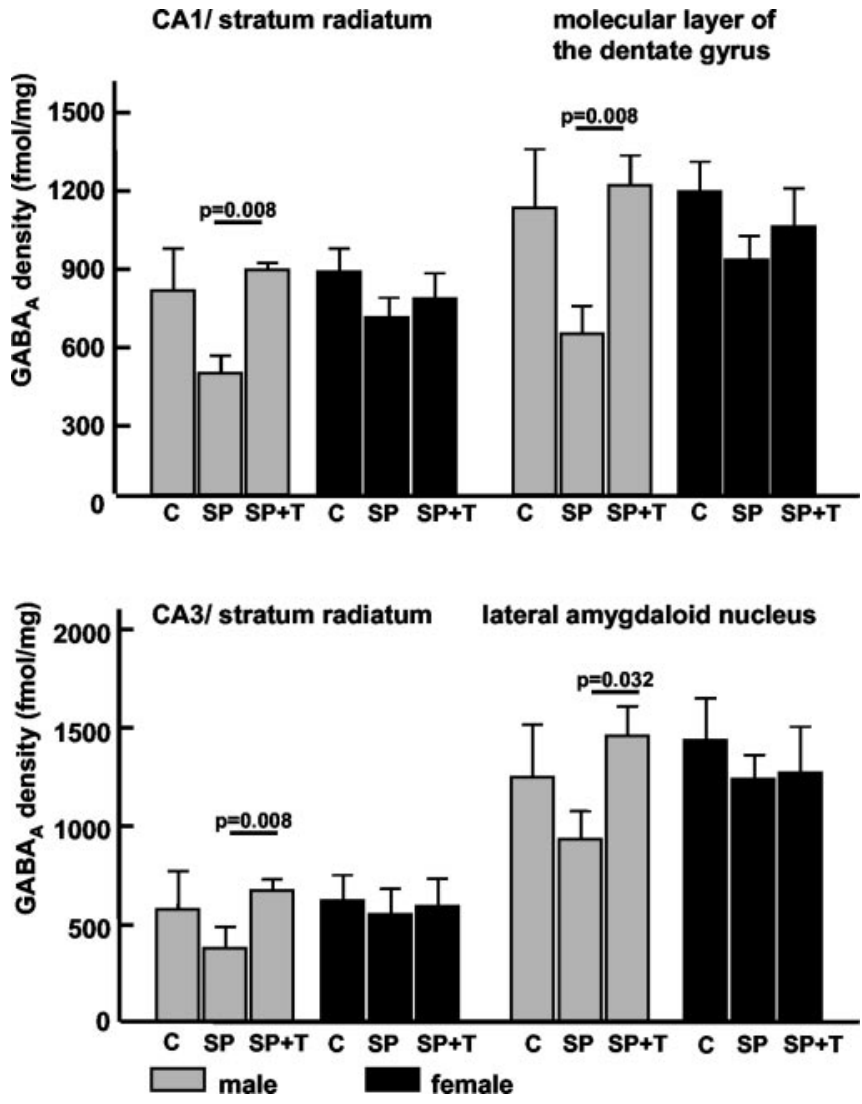

Figure 5. Parental separation with or without acoustic stimulation did not induce significant changes of $\mathrm{GABA}_{\mathrm{A}}$ receptor densities in the hippocampus and amydgala; however, a strong tendency toward $\mathrm{GABA}_{A}$ downregulation was observed in these regions. In the male pups, $G A B A_{A}$ values appear to be restored by the presence of maternal calls compared with the control group; a similar but weaker effect was seen in female pups. Values are mean with $\mathrm{SE} ; p$ values indicate results of two-tailed Mann-Whitney $U$ test. C, Control group; SP, separation from parents; $\mathrm{SP}+\mathrm{T}$, separation from parents + tone (maternal calls).

developmental time windows, might interfere with the development and maturation of synaptic networks. In addition to its function as neurotransmitter, serotonin (Whitaker-Azmitia et al., 1990, 1993, 1996; Lauder and Liu, 1994) and perhaps also dopamine (Laborit and Weber, 1966; Graybiel, 1991) was identified to act as "trophic" factor during early brain development.

\section{GABA: $G A B A_{A}$ receptors}

In contrast to the $\mathrm{D}_{1}$ and $5-\mathrm{HT} 1_{\mathrm{A}}$ receptors, the $\mathrm{GABA}_{\mathrm{A}}$ receptors did not show significant changes after short parental separation in relation to the untreated control group. A nonsignificant trend toward reduced densities of $\mathrm{GABA}_{\mathrm{A}}$ receptors was observed particularly in male pups, which is similar to the findings of a study in adult rats in which a significant reduction of $\mathrm{GABA}_{\mathrm{A}}$ receptor binding was found in the prefrontal cortex after chronic restraint stress (Otero Losada, 1988; Gruen et al., 1995).

Protective effects of maternal vocalizations on separationinduced receptor changes

In summary, our study revealed receptor-, region-, and genderspecific changes of monoaminergic receptor systems in the limbic system in response to a brief stressful episode (parental separation) and to acoustic emotional cues (maternal call). Our finding that the separation-induced receptor changes in limbic structures can be suppressed by maternal vocalizations strongly indicates that this suppression is mediated by the emotional rather than the 
acoustic features of this auditory stimulus. Behavioral and metabolic studies (Poeggel and Braun, 1996; Braun and Scheich, 1997; Braun and Poeggel, 2001) revealed that degu pups imprint on this maternal call during the first 2 weeks of their life, a juvenile learning process during which the newborn animals most likely form an association between the mother's vocalizations and being nursed and protected.

The "buffering" effect of the mother's voice on the separationinduced receptor changes support the hypothesis that the mother functions as regulator of the socio-emotional environment during early postnatal development. In particular, the emotional interaction via vocal communication between the dam and her pups may ameliorate anxiety and stress levels that are experienced by the pups during parental separation and exposure to an unfamiliar environment. Such subtle emotional regulatory interactions, which obviously can transiently or permanently alter brain activity levels (Poeggel and Braun, 1996; Braun and Scheich, 1997; Braun and Poeggel, 2001) as well as receptor densities, may play a critical role during the establishment and maintenance of limbic synaptic circuits (Helmeke et al. 2001a,b). Furthermore, such separation- and novelty-induced changes of brain activation and receptor patterns may induce cognitive and emotional/motivational changes in young animals and therefore are of particular relevance with respect to behavioral experiments that involve repeated testing procedures over periods of several days or weeks.

The acoustic presence of the mother during separation significantly suppressed the separation-induced $\mathrm{D}_{1}$ and $5-\mathrm{HT}_{\mathrm{A}}$ receptor upregulation; i.e., the $\mathrm{SP}+\mathrm{T}$ group displayed similar receptor densities as the untreated normal control group. This buffering effect of the maternal calls was observed primarily in the female pups, whereas in the male pups this effect was observed only for the $D_{1}$ receptors in the $C A 1 /$ stratum radiatum. The male pups displayed no significant changes of $D_{1}$ receptor density in the hippocampal formation (except in the CA1/stratum radiatum) and amygdala and also did not show changes in response to the presentation of the maternal calls, whereas the female pups displayed a separation-induced $D_{1}$ receptor upregulation in both brain areas that was buffered by the acoustic presence of the mother (except in the basolateral amygdala).

For the $5-\mathrm{HT}_{\mathrm{A}}$ receptors, the acoustic presence of the mother had a similar suppressive effect on separation-induced upregulation of $5-\mathrm{HT} 1_{\mathrm{A}}$ receptor density in the hippocampus of female pups. In the basomedial amygdala, a "paradoxical" genderspecific effect was observed. Although both genders did not show $5-\mathrm{HT} 1_{\mathrm{A}}$ receptor changes after separation alone, the presentation of the maternal call induced an increased receptor density in the male pups compared with the untreated control group, whereas in the female pups a significantly decreased receptor density was found compared with the untreated control group.

\section{Gender-specific effects of parental separation on receptors}

The present study revealed significantly higher basal levels of $5-\mathrm{HT} 1_{\mathrm{A}}$ receptors in the molecular layer of the dentate gyrus and CA3/stratum radiatum of female control pups compared with males from the control group. Furthermore, it is interesting that for both the $\mathrm{D}_{1}$ and $5-\mathrm{HT}_{\mathrm{A}}$ receptors, the brains of the female pups were more susceptible to the environmental changes compared with the male pups. Other rodent paradigms for changing neonatal emotional environments also seem to reveal genderspecific effects (Wigger and Neumann, 1999); however, the mechanisms involved in sexual differentiation of the CNS are not completely understood. Factors that may underlie such gender- specific responses toward neonatal environmental change may include direct or indirect interaction of gonadal hormones with the function of hypothalamic pituitary axis activation and monoaminergic systems. For instance, an influence of testosterone on cortical dopamine, but not on serotonin levels, has been found in rats (Battaner et al., 1987). Some recent studies indicate that a balance between glucocorticoids and androgens is necessary to maintain "normal" numbers of monoamine receptors in the brain and that estrogen can modulate brain dopamine receptor gene transcription (Lammers et al., 1999; Lee and Mouradian, 1999). Estrogen has specific regional effects on 5-HT functions in limbic regions through regulation of the $5-\mathrm{HT}_{\mathrm{A}}$ gene (Osterlund and Hurd, 1998), whereas testosterone can renormalize stressinduced changes of limbic 5-HT1 $1_{\mathrm{A}}$ receptors (Flugge et al., 1998).

\section{Possible functional implications}

Behavioral pharmacological and neurochemical experiments have revealed that the mesolimbic dopamine system is known to be involved in emotional behavior and learning events. Thus, separation-induced changes in monoaminergic modulation of the hippocampus and amygdala may result in altered functions such as deficits in spatial learning (Izquierdo et al., 1998; El Ghundi et al., 1999; Wilkerson and Levin, 1999; Barros et al., 2001) and of emotional behavior, in particular those associated with fear and anxiety (Davis et al., 1993; Lamont and Kokkinidis, 1998; Nader and Ledoux, 1999; Guarraci et al., 1999; Greba and Kokkinidis, 2000; Olivier et al., 2001; Zangrossi et al., 2001).

Interestingly, the limbic brain regions in which maternal vocalizations can alter activity patterns or receptor densities in the rodent pup are the same areas that in a human mother show responses to her infant's cries (Lorberbaum et al., 2002). Thus, stress-induced lasting changes in brain regions that play a role in emotional behavior during infancy may affect maternal behavior later in the adult and perhaps also limit other socio-emotional capacities. The clinical literature reveals that social loss and emotional deprivation are one of the most powerful antecedents to clinical depression (Furukawa et al., 1998, 1999; Draijer and Langeland, 1999; Agid et al., 1999). Maternal/parental separation is a widely used model to investigate the consequences of parental loss on the developing brain (McKinney et al., 1971; Suomi and Harlow, 1975; Suomi, 1991; Blass et al., 1995; Joseph, 1999; Kandel, 1999; Albright et al., 2000; Meaney, 2001). Separationinduced receptor changes and the resulting dysregulation of the glutamate (Ziabreva et al., 2000), GABA, and monoamine systems may contribute to the pathophysiology of various clinical disorders (Krystal et al., 2002) such as post-traumatic stress disorder (Spivak et al., 2000), attention deficit hyperactivity disorder (Daly et al., 1999; Andersen and Teicher, 2000; Sadile, 2000), depression (Sanacora et al., 2002), schizophrenia (Perry et al., 1984; Benes, 2000; Cotter et al., 2002; Reynolds et al., 2002), and autism (Dhossche et al., 2002).

\section{References}

Agid O, Shapira B, Zislin J, Ritsner M, Hanin B, Murad H, Troudart T, Bloch M, Heresco-Levy U, Lerer B (1999) Environment and vulnerability to major psychiatric illness: a case control study of early parental loss in major depression, bipolar disorder and schizophrenia. Mol Psychiatry 4:163-172.

Albright TD, Kandel ER, Posner MI (2000) Cognitive neuroscience. Curr Opin Neurobiol 10:612-624.

Andersen SL, Teicher MH (2000) Sex differences in dopamine receptors and their relevance to ADHD. Neurosci Biobehav Rev 24:137-141.

Avishai-Eliner S, Hatalski CG, Tabachnik E, Eghbal-Ahmadi M, Baram TZ (1999) Differential regulation of glucocorticoid receptor messenger 
RNA (GR-mRNA) by maternal deprivation in immature rat hypothalamus and limbic regions. Brain Res Dev Brain Res 114:265-268.

Barnard KE, Bee HL (1983) The impact of temporally patterned stimulation on the development of preterm infants. Child Dev 54:1156-1167.

Barros DM, Mello eSouza T, De David T, Choi H, Aguzzoli A, Madche C, Ardenghi P, Medina JH, Izquierdo I (2001) Simultaneous modulation of retrieval by dopaminergic $\mathrm{D}(1)$, beta-noradrenergic, serotonergic-1A and cholinergic muscarinic receptors in cortical structures of the rat. Behav Brain Res 124:1-7.

Battaner E, Rodriguez DC, Guerra M, Mas M (1987) Gonadal influences on spinal cord and brain monoamines in male rats. Brain Res 425:391-394.

Benes FM (2000) Emerging principles of altered neural circuitry in schizophrenia. Brain Res Brain Res Rev 31:251-269.

Blass EM, Shide DJ, Zaw-Mon C, Sorrentino J (1995) Mother as shield: differential effects of contact and nursing on pain responsivity in infant rats_evidence for nonopioid mediation. Behav Neurosci 109:342-353.

Borella A, Bindra M, Whitaker-Azmitia PM (1997) Role of the 5-HT1A receptor in development of the neonatal rat brain: preliminary behavioral studies. Neuropharmacology 36:445-450.

Braun K, Poeggel G (2001) Recognition of mother's voice evokes metabolic activation in the medial prefrontal cortex and thalamus of Octodon degus pups. Neuroscience 103:861-864.

Braun K, Lange E, Metzger M, Poeggel G (2000) Maternal separation followed by early social deprivation affects the development of monoaminergic fiber systems in the medial prefrontal cortex of Octodon degus. Neuroscience 95:309-318.

Braun K, Kremz P, Wetzel W, Wagner T, Poeggel G (2003) Influence of parental deprivation on the behavioral development in Octodon degus: modulation by maternal vocalizations. Dev Psychobiol 42:237-245.

Braun S, Scheich H (1997) Influence of experience on the representation of the "mothering call" in frontoparietal and auditory cortex of pups of the rodent Octodon degus: FDG mapping. J Comp Physiol [A] 181:697-709.

Caldji C, Francis D, Sharma S, Plotsky PM, Meaney MJ (2000) The effects of early rearing environment on the development of GABAA and central benzodiazepine receptor levels and novelty-induced fearfulness in the rat. Neuropsychopharmacology 22:219-229.

Chugani HT, Behen ME, Muzik O, Juhasz C, Nagy F, Chugani DC (2001) Local brain functional activity following early deprivation: a study of postinstitutionalized Romanian orphans. NeuroImage 14:1290-1301.

Clancy H, McBride G (1975) The isolation syndrome in childhood. Dev Med Child Neurol 17:198-219.

Cotter D, Landau S, Beasley C, Stevenson R, Chana G, MacMillan L, Everall I (2002) The density and spatial distribution of GABAergic neurons, labeled using calcium binding proteins, in the anterior cingulate cortex in major depressive disorder, bipolar disorder, and schizophrenia. Biol Psychiatry $51: 377-386$.

Coudereau JP, Monier C, Frances H (1995) Effect of isolation on behavioural models involving serotonergic 5-HT2 and 5-HT1A receptors. Prog Neuropsychopharmacol Biol Psychiatry 19:931-942.

Daly G, Hawi Z, Fitzgerald M, Gill M (1999) Mapping susceptibility loci in attention deficit hyperactivity disorder: preferential transmission of parental alleles at DAT1, DBH and DRD5 to affected children. Mol Psychiatry 4:192-196.

Daval G, Verge D, Becerril A, Gozlan H, Spampinato U, Hamon M (1987) Transient expression of 5-HT1A receptor binding sites in some areas of the rat CNS during postnatal development. Int J Dev Neurosci 5:171-180.

Davis M, Falls WA, Campeau S, Kim M (1993) Fear-potentiated startle: a neural and pharmacological analysis. Behav Brain Res 58:175-198.

DeCasper AJ, Fifer WP (1980) Of human bonding: newborns prefer their mothers' voices. Science 208:1174-1176.

Dhossche D, Applegate H, Abraham A, Maertens P, Bland L, Bencsath A, Martinez J (2002) Elevated plasma gamma-aminobutyric acid (GABA) levels in autistic youngsters: stimulus for a GABA hypothesis of autism. Med Sci Monit 8:R1-R6.

Draijer N, Langeland W (1999) Childhood trauma and perceived parental dysfunction in the etiology of dissociative symptoms in psychiatric inpatients. Am J Psychiatry 156:379-385.

El Ghundi M, Fletcher PJ, Drago J, Sibley DR, O’Dowd BF, George SR (1999) Spatial learning deficit in dopamine $\mathrm{D}(1)$ receptor knockout mice. Eur J Pharmacol 383:95-106.

Fifer WP, Moon CM (1994) The role of mother's voice in the organization of brain function in the newborn. Acta Paediatr [Suppl] 397:86-93.
Fleming AS, O’Day DH, Kraemer GW (1999) Neurobiology of mother-infant interactions: experience and central nervous system plasticity across development and generations. Neurosci Biobehav Rev 23:673-685.

Flugge G, Kramer M, Rensing S, Fuchs E (1998) 5HT1A-receptors and behaviour under chronic stress: selective counteraction by testosterone. Eur J Neurosci 10:2685-2693.

Furukawa T, Mizukawa R, Hirai T, Fujihara S, Kitamura T, Takahashi K (1998) Childhood parental loss and schizophrenia: evidence against pathogenic but for some pathoplastic effects. Psychiatry Res 81:353-362.

Furukawa TA, Ogura A, Hirai T, Fujihara S, Kitamura T, Takahashi K (1999) Early parental separation experiences among patients with bipolar disorder and major depression: a case-control study. J Affect Disord 52:85-91.

Graybiel AM (1991) Basal ganglia-input, neural activity, and relation to the cortex. Curr Opin Neurobiol 1:644-651.

Greba Q, Kokkinidis L (2000) Peripheral and intraamygdalar administration of the dopamine D1 receptor antagonist SCH 23390 blocks fearpotentiated startle but not shock reactivity or the shock sensitization of acoustic startle. Behav Neurosci 114:262-272.

Gruen RJ, Wenberg K, Elahi R, Friedhoff AJ (1995) Alterations in GABA(A) receptor binding in the prefrontal cortex following exposure to chronic stress. Brain Res 684:112-114.

Guarraci FA, Frohardt RJ, Kapp BS (1999) Amygdaloid D1 dopamine receptor involvement in Pavlovian fear conditioning. Brain Res 827:28-40.

Hall FS (1998) Social deprivation of neonatal, adolescent, and adult rats has distinct neurochemical and behavioral consequences. Crit Rev Neurobiol 12:129-162.

Hall FS, Wilkinson LS, Humby T, Inglis W, Kendall DA, Marsden CA, Robbins TW (1998) Isolation rearing in rats: pre- and postsynaptic changes in striatal dopaminergic systems. Pharmacol Biochem Behav 59:859-872.

Hall FS, Wilkinson LS, Humby T, Robbins TW (1999) Maternal deprivation of neonatal rats produces enduring changes in dopamine function. Synapse 32:37-43.

Harvey AT, Moore H, Lucot JB, Hennessy MB (1994) Monoamine activity in anterior hypothalamus of guinea pig pups separated from their mothers. Behav Neurosci 108:171-176.

Helmeke C, Ovtscharoff Jr W, Poeggel G, Braun K (2001a) Juvenile emotional experience alters synaptic inputs on pyramidal neurons in the anterior cingulate cortex. Cereb Cortex 11:717-727.

Helmeke C, Poeggel G, Braun K (2001b) Differential emotional experience induces elevated spine densities on basal dendrites of pyramidal neurons in the anterior cingulate cortex of Octodon degus. Neuroscience 104:927-931.

Izquierdo I, Medina JH, Izquierdo LA, Barros DM, de Souza MM, Mello eSouza T (1998) Short- and long-term memory are differentially regulated by monoaminergic systems in the rat brain. Neurobiol Learn Mem 69:219-224.

Jones GH, Hernandez TD, Kendall DA, Marsden CA, Robbins TW (1992) Dopaminergic and serotonergic function following isolation rearing in rats: study of behavioural responses and postmortem and in vivo neurochemistry. Pharmacol Biochem Behav 43:17-35.

Joseph R (1999) Environmental influences on neural plasticity, the limbic system, emotional development and attachment: a review. Child Psychiatry Hum Dev 29:189-208.

Kandel ER (1999) Biology and the future of psychoanalysis: a new intellectual framework for psychiatry revisited. Am J Psychiatry 156:505-524.

Kehoe P, Clash K, Skipsey K, Shoemaker WJ (1996) Brain dopamine response in isolated 10-day-old rats: assessment using D2 binding and dopamine turnover. Pharmacol Biochem Behav 53:41-49.

Krystal JH, Sanacora G, Blumberg H, Anand A, Charney DS, Marek G, Epperson CN, Goddard A, Mason GF (2002) Glutamate and GABA systems as targets for novel antidepressant and mood-stabilizing treatments. Mol Psychiatry 7[Suppl 1]:S71-S80.

Laborit H, Weber B (1966) Trial interpretation of the metabolic mode of action of certain neurotropic agents. VII. Dopamine. Agressologie 7:31-41.

Lammers CH, D’Souza U, Qin ZH, Lee SH, Yajima S, Mouradian MM (1999) Regulation of striatal dopamine receptors by estrogen. Synapse 34:222-227.

Lamont EW, Kokkinidis L (1998) Infusion of the dopamine D1 receptor antagonist SCH 23390 into the amygdala blocks fear expression in a potentiated startle paradigm. Brain Res 795:128-136. 
Lauder JM, Liu J (1994) Glial heterogeneity and developing neurotransmitter systems. Perspect Dev Neurobiol 2:239-250.

Lee SH, Mouradian MM (1999) Up-regulation of D1A dopamine receptor gene transcription by estrogen. Mol Cell Endocrinol 156:151-157.

Lorberbaum JP, Newman JD, Horwitz AR, Dubno JR, Lydiard RB, Hamner MB, Bohning DE, George MS (2002) A potential role for thalamocingulate circuitry in human maternal behavior. Biol Psychiatry 51:431-445.

Martin LJ, Spicer DM, Lewis MH, Gluck JP, Cork LC (1991) Social deprivation of infant rhesus monkeys alters the chemoarchitecture of the brain: I. Subcortical regions. J Neurosci 11:3344-3358.

Matthews K, Dalley J, Matthews C, Hu TT, Robbins T (2001) Periodic maternal separation of neonatal rats produces region- and gender-specific effects on biogenic amine content in postmortem adult brain. Synapse 40:1-10.

McKinney Jr WT, Suomi SJ, Harlow HF (1971) Depression in primates. Am J Psychiatry 127:1313-1320.

Meaney MJ (2001) Maternal care, gene expression, and the transmission of individual differences in stress reactivity across generations. Annu Rev Neurosci 24:1161-1192.

Meaney MJ, Brake W, Gratton A (2002) Environmental regulation of the development of mesolimbic dopamine systems: a neurobiological mechanism for vulnerability to drug abuse? Psychoneuroendocrinology 27:127-138.

Mendelson SD, McEwen BS (1991) Autoradiographic analysis of the effects of restraint-induced stress on 5-HT1A, 5HT1C, and 5-HT2 receptors in the dorsal hippocampus of male and female rats. Neuroendocrinology 54:454-461.

Nader K, Ledoux JE (1999) Inhibition of the mesoamygdala dopaminergic pathway impairs the retrieval of conditioned fear associations. Behav Neurosci 113:891-901.

Neumaier JF, Edwards E, Plotsky PM (2002) 5-HT(1B) MRNA regulation in two animal models of altered stress reactivity. Biol Psychiatry 51:902-908.

Olivier B, Pattij T, Wood SJ, Oosting R, Sarnyai Z, Toth M (2001) The 5-HT(1A) receptor knockout mouse and anxiety. Behav Pharmacol 12:439-450.

Osterlund MK, Hurd YL (1998) Acute 17 beta-estradiol treatment downregulates serotonin 5 HT1A receptor mRNA expression in the limbic system of female rats. Brain Res Mol Brain Res 55:169-172.

Otero Losada ME (1988) Changes in central GABAergic function following acute and repeated stress. Br J Pharmacol 93:483-490.

Perry TL, Ito M, Jones K, Hansen S (1984) Elevation of gammaaminobutyric acid in human brain may increase dopaminergic neuronal function. Neurosci Lett 50:67-71.

Poeggel G, Braun K (1996) Early auditory filial learning in degus (Octodon degus): behavioral and autoradiographic studies. Brain Res 743:162-170.

Rasmuson S, Olsson T, Henriksson BG, Kelly PA, Holmes MC, Seckl JR, Mohammed AH (1998) Environmental enrichment selectively increases 5-HT1A receptor mRNA expression and binding in the rat hippocampus. Brain Res Mol Brain Res 53:285-290.

Reynolds TJ, Wright JW (1979) Early postnatal physical and behavioural development of degus (Octodon degus). Lab Anim 13:93-100.

Reynolds GP, Beasley CL, Zhang ZJ (2002) Understanding the neurotransmitter pathology of schizophrenia: selective deficits of subtypes of cortical GABAergic neurons. J Neural Transm 109:881-889.

Sadile AG (2000) Multiple evidence of a segmental defect in the anterior forebrain of an animal model of hyperactivity and attention deficit. Neurosci Biobehav Rev 24:161-169.

Sanacora G, Mason GF, Rothman DL, Krystal JH (2002) Increased occipital cortex GABA concentrations in depressed patients after therapy with selective serotonin reuptake inhibitors. Am J Psychiatry 159:663-665.

Schnabel R, Braun K (1996) Development of dopamine receptors in the forebrain of the domestic chick in relation to auditory imprinting an autoradiographic study. Brain Res 720:120-130.

Spivak B, Maayan R, Kotler M, Mester R, Gil-Ad I, Shtaif B, Weizman A (2000) Elevated circulatory level of GABA(A) — antagonistic neurosteroids in patients with combat-related post-traumatic stress disorder. Psychol Med 30:1227-1231.

Suomi SJ (1991) Primate separation models of affective disorders. In: Neurobiology of learning/emotion and affect (Madden J, ed), pp 195-214. New York: Raven.

Suomi SJ, Harlow HF (1975) Effects of differential removal from group on social development of Rhesus monkeys. J Child Psychol Psychiatry 16:149-164.

Sutanto W, Rosenfeld P, De Kloet ER, Levine S (1996) Long-term effects of neonatal maternal deprivation and ACTH on hippocampal mineralocorticoid and glucocorticoid receptors. Brain Res Dev Brain Res 92:156-163.

Swann JW, Pierson MG, Smith KL, Lee CL (1999) Developmental neuroplasticity: roles in early life seizures and chronic epilepsy. Adv Neurol 79:203-216.

Tamborski A, Lucot JB, Hennessy MB (1990) Central dopamine turnover in guinea pig pups during separation from their mothers in a novel environment. Behav Neurosci 104:607-611.

Vazquez DM, Lopez JF, Van Hoers H, Watson SJ, Levine S (2000) Maternal deprivation regulates serotonin $1 \mathrm{~A}$ and $2 \mathrm{~A}$ receptors in the infant rat. Brain Res 855:76-82.

Walsh RN (1981) Effects of environmental complexity and deprivation on brain anatomy and histology: a review. Int J Neurosci 12:33-51.

Whitaker-Azmitia P (1993) The role of serotonin and serotonin receptors in development of the mammalian nervous system. In: Neurotransmitters (Zagon IS, McLaughlin PJ, eds), pp 43-53. London: Chapman and Hall.

Whitaker-Azmitia PM, Shemer AV, Caruso J, Molino L, Azmitia EC (1990) Role of high affinity serotonin receptors in neuronal growth. Ann NY Acad Sci 600:315-330.

Whitaker-Azmitia PM, Druse M, Walker P, Lauder JM (1996) Serotonin as a developmental signal. Behav Brain Res 73:19-29.

Wigger A, Neumann ID (1999) Periodic maternal deprivation induces gender-dependent alterations in behavioral and neuroendocrine responses to emotional stress in adult rats. Physiol Behav 66:293-302.

Wilkerson A, Levin ED (1999) Ventral hippocampal dopamine D1 and D2 systems and spatial working memory in rats. Neuroscience 89:743-749.

Wright JW, Kern MD (1992) Stereotaxic atlas of the brain of Octodon degus. J Morphol 214:299-320.

Zangrossi Jr H, Viana MB, Zanoveli J, Bueno C, Nogueira RL, Graeff FG (2001) Serotonergic regulation of inhibitory avoidance and one-way escape in the rat elevated T-maze. Neurosci Biobehav Rev 25:637-645.

Ziabreva I, Schnabel R, Braun K (2000) Parental deprivation induces $\mathrm{N}$-methyl-D-aspartate-receptor upregulation in limbic brain areas of $\mathrm{Oc}$ todon degus: protective role of the maternal call. Neural Plast 7:233-244.

Ziabreva I, Schnabel R, Poeggel G, Braun K (2003) Mother's voice "buffers" separation-induced receptor changes in the prefrontal cortex of Octodon degus. Neuroscience, in press. 